Received Date : 23-May-2016

Revised Date : 06-Sep-2016

Accepted Date : 06-Sep-2016

Article type : Original Article

Running head: S. tanaceti infected seed and seedlings

\title{
Infection process of Stagonosporopsis tanaceti in pyrethrum seed and seedlings
}

\author{
M. A. H. B. Bhuiyan ${ }^{a}$, T. Groom ${ }^{b}$, M. E. Nicolas ${ }^{a}$ and P. W. J. Taylor ${ }^{a *}$ \\ ${ }^{a}$ Faculty of Veterinary and Agricultural Sciences, The University of Melbourne, Parkville, \\ Victoria-3010; and ${ }^{\mathrm{b} B o t a n i c a l ~ R e s o u r c e s ~ A u s t r a l i a ~-~ A g r i c u l t u r a l ~ S e r v i c e s ~ P t y . ~ L t d, ~}$ \\ Ulverstone, Tasmania, Australia
}

*E-mail: paulwjt@unimelb.edu.au

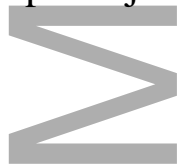

Ray blight disease of pyrethrum (Tanacetum cinerariifolium) is caused by Stagonosporopsis tanaceti, with infected seed being a major means of transmission of this fungal pathogen. The infection process of $S$. tanaceti in pyrethrum seed and seedlings was determined. Infection hyphae only infected the outer and inner layers of the seed coat and not the embryo of naturally infected pyrethrum seed. During the process of germination of infected seed, $S$. tanaceti from the seed coat infected the developing embryo and cotyledon, resulting in preand post-emergence death, depending on the level of infection in the seed coat. Preemergence death occurred due to disintegration of the infected embryo, which was replaced by hyphae and extracellular anthocyanin-like material (EAM) at 7 days after incubation (dai). Post-emergence death occurred after both epidermal and cortical tissues of infected cotyledons at the crown/hypocotyl region disintegrated due to colonization by hyphae.

Moreover, most of the tissues of the vascular bundles and cortical tissues contained heavy

This is the author manuscript accepted for publication and has undergone full peer review but has not been through the copyediting, typesetting, pagination and proofreading process, which may lead to differences between this version and the Version of Record. Please cite this article as doi: $10.1111 /$ ppa.12622

This article is protected by copyright. All rights reserved 
depositions of EAM at 10-14 dai. In 6-week-old infected seedlings, hyphae were confined to the epidermis and the cortical tissues at the crown/hypocotyl regions; the vascular bundles of both infected and uninfected regions, and cortical tissues of the uninfected regions of the seedlings were completely free from infection hyphae and EAM. These findings provide a better understanding of the early stages of the disease cycle of S. tanaceti and will lead to improved control measures for seedborne infection using seed treatments.

Keywords: histopathology, pyrethrum seed, ray blight, seedling, Stagonosporopsis tanaceti

\section{Introduction}

Pyrethrum, Tanacetum cinerariifolium, is a perennial herbaceous plant grown commercially in Australia for the production of pyrethrin-based pesticides (Hitmi et al., 2000). Pyrethrins are produced primarily in the secretory ducts in the flowers and leaf tissues (Zito et al., 1983). About 3000 ha of pyrethrum are grown in Australia, mostly in northern Tasmania and the Ballarat region of Victoria, and account for the majority of production worldwide (Hay et $a l .$, 2015). Other pyrethrum producing countries are Kenya, Rwanda, Tanzania, China and Papua New Guinea (Pethybridge et al., 2008).

Seeds are the major planting material to establish pyrethrum fields in late winter and early spring (July to September), but vegetative clones are also used as planting materials (Pethybridge et al., 2008). First harvest is in December and January of the following year (15-17 months after planting), after which up to three annual harvests are conducted. The commercial life span of pyrethrum is three to five years (Pethybridge et al., 2008; Vaghefi et al., 2015b). The yield of pyrethrum is dependent on the number of harvestable flowers, size of individual flowers and pyrethrin content in each flower (Pethybridge et al., 2007).

Three phylogenetically closely related Stagonosporospsis species, S. tanaceti, S. chysanthemi and S. inoxydabilis, were shown to be the causal agents of ray blight disease on multiple plants in the Asteraceae family worldwide (Vaghefi et al., 2012). However, $S$. tanaceti has so far been identified as the only causal agent of ray blight of pyrethrum in Australia (Pethybridge \& Wilson, 1998; Vaghefi et al., 2012). This disease affects flower development and, therefore, is considered a major threat to the production of pyrethrum. Epidemics of ray blight in pyrethrum were reported to occur most prevalently during early 
spring in Tasmania, Australia (Pethybridge et al., 2003). Previous studies reported that yield decline of pyrethrum due to the necrosis of terminal flower buds was managed with the use of fungicides in early spring (Pethybridge et al., 2005, 2007). The teleomorph or sexual stage has been identified in S. chysanthemi and S. inoxydabilis; however, the sexual stage has not been found in S. tanaceti in Australia (Vaghefi et al., 2015a). For S. chrysanthemi, the sexual stage was thought to play a vital role in long distance dispersal by ascospores (MacCoy, 1973). In ray blight of pyrethrum, dispersal of $S$. tanaceti has been shown to occur by splash/wind dispersal of conidia released from pycnidia, which developed within the necrotic leaf tissues of the infected pyrethrum plants (Pethybridge et al., 2008; Bhuiyan et al., 2015), and by seedborne infection (Pethybridge et al., 2008).

Seed colonization is a long-term survival mechanism of fungi and is responsible for vertical transmission from the parent to the offspring through infected seeds (Oliver et al., 2001) or horizontal transmission of pathogens from infected to healthy hosts through direct contact (van den Bosch et al., 2010). Pyrethrum seeds are considered to be the major source of transmission of $S$. tanaceti over long distances resulting in severe disease epidemics (Pethybridge et al., 2008); however, the movement of infection hyphae from seed to seedlings is unknown. Therefore, the objectives of this study were to determine the biology of seed infection and the transmission mechanism of $S$. tanaceti from pyrethrum seed to seedlings.

\section{Materials and methods}

\section{Seed batches}

Batches of seed were collected in 2014 from seed lots of cultivars BR1 (at Forth in North West Tasmania) and RS5 (at Kindred in North West Tasmania) grown in commercial fields. At the Tasmanian Institute of Agriculture (TIA), seeds from these two cultivars were assessed as being 30-35\% infected with $S$. tanaceti by direct culturing of dry, raw seeds on water agar (WA) plates. Identification of S. tanaceti was based on floccose and white aerial mycelia, growth rate on WA that varied from 65 to $75 \mathrm{~mm}$ per 7 days and rare development of pycnidia. Additional seed batches of both the cultivars, from the same geographic locations, were hot water treated following the procedure described by Schmitt et al. (2009). This 
procedure reduced $S$. tanaceti to a nondetectable level after culturing treated infected seed on WA plates.

\section{Morphology, anatomy and histopathology of heat-treated and infected seed}

Ten seeds, randomly selected from each of the infected and heat-treated (control) seed lots of the two cultivars, were separately washed twice with sterile deionized water (SDW) for 5 min followed by drying in a laminar flow cabinet. These seeds were examined using a stereomicroscope (M 205 FA; Leica Biosystems) to identify the presence of necrotic lesions and fungal hyphae or fruiting bodies on the seed surface as well as morphological features, and the average size of each seed was measured.

Each seed was then equally divided transversely into two pieces using a sterile razor blade; one half was prepared for culturing on WA with incubation at $20^{\circ} \mathrm{C}$ for 7 days, and the other half was processed for histopathology. On WA, mycelium that grew was at first identified as described above, then subcultured onto V8 medium (200 mL V8 juice and $20 \mathrm{~g}$ agar in $1 \mathrm{~L}$ sterile water, $\mathrm{pH}$ 6.25) for 2 weeks to confirm $S$. tanaceti as described by Pethybridge \& Wilson (1998). For histopathology, the seed tissue was transferred to FAA ( $10 \%$ formalin, $5 \%$ acetic acid and $50 \%$ ethanol) for $12 \mathrm{~h}$ followed by dehydration in an ethanol series (30\%, 70\% and 100\% for 5 min each) and then embedded in paraffin and stored at $20^{\circ} \mathrm{C}$. Three samples from each of $S$. tanaceti infected and control seeds of the two cultivars were selected for sectioning using a rotary microtome (RM 2125 RTS; Leica Biosystems). The thickness of each section was maintained at 7-8 $\mu \mathrm{m}$. Sections were stained using quadruple stain (Johansen, 1940) as described by Bhuiyan et al. (2015).

At least 10 serial sections from each of the control and infected seeds of each cultivar were used to describe the anatomy of the seed and to locate infection hypha in the seed components using light microscopy (DM 6000 B; Leica Biosystems). Both anatomical and histopathological features were recorded by capturing the images with a digital camera (DFC $450 \mathrm{C}$; Leica Biosystems) using both bright field (BF) and differential interference contrast (DIC) microscopy.

\section{Assessment of infection in seed tissues and survival of the embryo}


Forty seeds, collected randomly from the naturally infected seed lots (30-35\% S. tanacetiinfected) of cultivars BR1 and RS5, were soaked in SDW for 30 min. Seeds were dissected aseptically using a stereomicroscope and sterile needles to separate different tissues of the seed, then surface sterilized using sodium hypochlorite (1\% active ingredient (a.i.)) for 2 min followed by washing in two changes of SDW. Seed tissues from each seed were then blotted with sterile Kim wipes, placed onto WA in a $90 \mathrm{~mm}$ Petri plate and incubated at $20{ }^{\circ} \mathrm{C}$ with $12 \mathrm{~h}$ alternating dark and light for 2 weeks. Stagonosporopsis tanaceti associated with the seed tissues was identified as described above. The infection in each seed tissue was assessed and the prevalence of infection was calculated by counting the number of infected tissue samples in 40 seeds as follows:

$$
\text { Prevalence of infection }(\%)=\frac{\text { Number of infected tissue samples }}{\text { Total number of tissue samples plated }} \times 100
$$

Survival rate of the 40 dissected embryos that developed into seedlings on WA at 14 days after incubation (dai) and had no infection hyphae around the seedling was calculated as follows:

$$
\text { Survival rate (\%) }=\frac{\text { Number of embryos that developed into seedlings }}{\text { Total number of embryos plated }} \times 100
$$

\section{Classification of infected seeds}

One thousand naturally infected pyrethrum seeds (30-35\% S. tanaceti-infected) from cultivar BR1 were surface sterilized using sodium hypochlorite (1\% a.i.) for $2 \mathrm{~min}$, washed in two changes of SDW, blotted with sterile Kim wipes, placed onto WA (1\% agar; 15 seeds per plate) in $90 \mathrm{~mm}$ Petri dishes and incubated at $20{ }^{\circ} \mathrm{C}$ for 2 weeks. Fungi that grew around each seed were identified based on the colony morphology on WA at 7 dai and from subcultures on V8 medium.

The occurrence of infection was assessed in 20 plates and classified after 1-2 weeks incubation as (i) seeds that completely failed to germinate at 7 dai - pre-emergence death; (ii) seeds where the cotyledons emerged completely from the infected seed coat but eventually died at 10-14 dai - post-emergence death; (iii) seeds where the embryo developed into 
seedlings with $S$. tanaceti infection hyphae around the seed coat - infected seedlings; (iv) seeds where the embryo developed into seedlings with no infection hyphae around the seed coat - noninfected, healthy seedlings; (v) seeds where the embryo failed to germinate without any infection hyphae around the seeds - nonviable seeds; (vi) seeds that completely failed to germinate due to infection caused by fungi other than $S$. tanaceti at 7 dai. The occurrence of these events in 20 plates was analysed by one-way analysis of variance (ANOVA) using MINITAB v. 16 (State College PA, Minitab Inc.). Means were separated using a Tukey's honestly significant difference mean separation test at $(P<0.05)$.

Development of all S. tanaceti-infected seedlings was monitored for lesion development from 1 to 7 dai and expressed as a percentage over the total number of infected seedlings at 7 dai.

For the histological study, five infected seeds were randomly sampled every $24 \mathrm{~h}$ starting from 3 until 7 dai from 300 naturally infected seeds incubated on WA plates. After germination, five seedlings that died of infection caused by $S$. tanaceti at 10-14 dai were also collected randomly. Both infected seeds and seedlings were separately processed for histopathology as described above.

\section{Raising of infected seedlings}

Thirty S. tanaceti-infected seedlings, raised from the remaining 400 naturally infected seeds on WA plates at 14 dai, were collected randomly. These seedlings were transplanted separately into small pots (diameter $5.5 \mathrm{~cm}$ ) containing steam-sterilized potting mix (Seed Raising $25 \mathrm{~L}$; Debco) and incubated at $25{ }^{\circ} \mathrm{C}$ in the glasshouse with $12 \mathrm{~h}$ alternating dark and light. Six weeks after planting, 20 seedlings were uprooted, washed three times in SDW, surface sterilized using $\mathrm{NaOCl}$ ( $1 \%$ a.i.) for $2 \mathrm{~min}$, then washed in two changes of SDW followed by blotting on sterile Kim wipes. Ten seedlings were examined for necrosis and were separately dissected into $1 \mathrm{~cm}$ pieces using a sterile sharp razor blade in a sequential order, starting from the root tip towards the shoot tip, and placed onto 1\% WA in Petri plates. Mycelia that grew out from the tissue were subcultured onto V8 medium to confirm the presence of $S$. tanaceti and the location (in $\mathrm{cm}$ ) of infection from the tip of the radicle to the tip of the epicotyl for each infected seedling was recorded. 
Another 10 seedlings were selected and processed for histopathology by separately dissecting a $1 \mathrm{~cm}$ tissue piece from each of the epicotyl/shoot (top), crown/ hypocotyl (mid) and radicle/root (bottom) regions.

The remaining 10 seedlings were grown for 8 weeks to monitor development of necrotic lesions on the above-ground part (epicotyl/shoot) of each seedling.

\section{Comparative establishment of seedlings from infected and heat-treated seeds}

A total of 125 seeds from each seed lot of naturally infected (30-35\% S. tanaceti-infected) and heat-treated seeds from cultivar BR1 were sown in potting mix (Seed Raising $25 \mathrm{~L}$; Debco) on two separate trays $(30 \times 35 \mathrm{~cm})$ and grown in the glasshouse at $25^{\circ} \mathrm{C}$ for 6 weeks. The trays were irrigated with $150 \mathrm{~mL}$ water per tray per day using a sprinkler irrigation system. After 6 weeks, the rate of germination was calculated as a percentage and the length of all seedlings in a tray were measured and the average calculated. Seedlings were visually examined for necrotic lesions and the positions of these lesions were recorded. Seedlings were separately surface sterilized and cut into $1 \mathrm{~cm}^{2}$ pieces, starting from the tip of the radicle to the tip of the epicotyl, then plated onto WA and incubated at $20^{\circ} \mathrm{C}$ for 7 days with $12 \mathrm{~h}$ alternating dark and light. Subculturing onto V8 medium confirmed S. tanaceti in each infected tissue piece and the position of infection (in $\mathrm{cm}$ ) in each seedling was also recorded.

\section{Results}

\section{Morphology, anatomy and histopathology of control and infected seed}

None of the naturally infected seeds from either cultivar (BR1 and RS5) showed visible lesions, hyphae or pycnidia, or structural abnormalities on the seed surface. The size of pyrethrum seeds varied in length and width from $3-5.5 \mathrm{~mm} \times 0.4-0.6 \mathrm{~mm}$ for both cultivars. Each seed had five distinct ridges and a pappus (modified calyx; Fig. 1a). The pappus was roundish (0.45-0.50 mm diameter) and was permanently fixed to the outer layer of the seed coat. There was an empty space (depth $0.25-0.35 \mathrm{~mm}$ ) around the pappus (Fig. 1b).

Pyrethrum seed largely consisted of seed coat and an embryo (Fig. 1c). The seed coat had a waxy cuticle layer of 4-5 $\mu \mathrm{m}$ thickness (Fig. 1d). The seed coat consisted of three 
distinct layers: (i) outer layer $(60-80 \mu \mathrm{m})$ which was composed of two- to three-cell layers of sclerenchyma tissue; (ii) first inner layer $(10-15 \mu \mathrm{m})$ composed of a one-cell layer of sclerenchyma tissue; (iii) second inner layer (10-12 $\mu \mathrm{m})$ composed of a one-cell layer of parenchyma tissue. The embryo $(600-700 \mu \mathrm{m})$ consisted of multi-layered homogenous parenchyma cells. There was a 20-27 $\mu$ m gap between the seed coat and the embryo (Fig. 1d). The top surface of the seed coat was not continuous and contained fissures or spaces (Fig. 1e). The arrangement and composition of tissues in seed components of both cultivars were similar.

Stagonosporopsis tanaceti infection hyphae were observed in the outer layer of infected seeds in both cultivars (Fig. 1f) but were not observed in any other layers of the seed coat or in the embryo. Hyphae were absent from all the components of control seeds in both cultivars.

\section{Assessment of infection in seed components and survival of the embryo}

Although $S$. tanaceti infection hyphae were only visible in the outer layer of infected seed using histopathology, they were identified in both outer and inner layers of the seed coat tissue that was cultured on WA and V8 medium. The prevalence of $S$. tanaceti was much higher $(30.0 \%$ and $27.5 \%)$ in the outer layer than the first inner layer $(5.0 \%$ and $7.5 \%)$ in cultivars BR1 and RS5 respectively. Only $2.5 \%$ of seed of cultivar BR1 had a second inner layer infected by S. tanaceti. Meanwhile, $5.0 \%$ of seed of BR1 and $2.5 \%$ of seed of RS5 had an outer layer of the seed coat infected by fungi other than $S$. tanaceti, which were absent from the inner layers. All the dissected embryos from both cultivars were free from infection. There was $100 \%$ survival rate of the dissected embryos of both cultivars and all developed into seedlings by 14 dai on WA.

\section{Classification of infected seeds}

An average of $19.3 \%$ and $3.7 \%$ of seeds per plate failed to germinate due to pre- and postemergence death caused by $S$. tanaceti, respectively. Occurrence of pre-emergence death was significantly higher than post-emergence death. There were a significant number of seedlings, $44.7 \%$ per plate, that developed without any infection (healthy seedlings), compared to $9.0 \%$ 
per plate that were infected by S. tanaceti. There were also non-viable and non-infected seeds, $21.3 \%$ per plate, that failed to germinate; and a very few seeds, $2.0 \%$ per plate, that failed to germinate due to infection by fungi other than $S$. tanaceti (Table 1).

Of all the $S$. tanaceti-infected cotyledons, only $20 \%$ developed red necrosis at the crown/hypocotyl region of the seedlings (Fig. 2a) at 3-5 dai, which later extended and covered the crown region by 7 dai (Fig. 2b). The remaining $S$. tanaceti-infected seedlings $(80 \%)$ were symptomless.

Infection hyphae were observed in the seed coat, but not in the parenchyma tissues, of the embryo at 3 dai. Hyphae were present in the longitudinal sections (LS) of fissures/spaces of the outer layer (Fig. 3a) and in transverse sections (TS) of the intra- and intercellular spaces of sclerenchyma cells of the outer layer (Fig. 3b). Among the inner layers, hyphae were only seen in the parenchyma cells of the second inner layer. In addition, hyphae were observed between the outer and the inner layer (Fig. 3c). At this stage, despite infection by the hyphae, tissues in the outer seed coat appeared unchanged.

At 5 dai, hyphae in the seed coat infected the developing embryo, but parenchyma tissues of the embryo, middle lamellae and also the tissue colour were unchanged (Fig. 3d). At 6 dai the infection progressed further, with mycelia colonizing in and around the embryo, resulting in light yellow to yellow brown lesions. Moreover, infected epidermal tissues were collapsed and degraded (Fig. 3e). Necrotic lesions spread rapidly into the whole embryo, which resulted in the disintegration of the parenchyma tissues that appeared yellow at 7 dai. Middle lamellae of the parenchyma tissues were not visible. In addition to infection hyphae, red extracellular anthocyanin-like material (EAM) was present at the infection site (Fig. 3f). The necrosis and tissue degradation were more prevalent in the radicle than epicotyl region of the embryo. No necrotic lesions were seen in the outer layer of the seed coat.

Sections of $S$. tanaceti-infected seeds that failed to germinate at 7 dai showed complete collapse of the tissue of the embryo, which was replaced by mycelia and red EAM (Fig. 4a). The epidermis (one-cell parenchyma layer) of $S$. tanaceti-infected cotyledons (Fig. 4b) that died at 10-14 dai was degraded and replaced by mycelia and EAM (Fig. 4c). Among the vascular tissues, almost all phloem tissues and most of the xylem vessels contained EAM but were not infected (Fig. 4c,d). Most of the cortical tissue (five- to six-cell parenchyma layer) below the epidermis was lysed due to colonization by masses of hyphae, with the cell contents digested or depleted and eventually replaced by the red EAM (Fig. 4c,e). 


\section{Raising of infected seedlings}

All 30 infected seedlings developed normally during their different growth stages in the potting mix over 6 weeks; however, all seedlings were found to be infected with $S$. tanaceti at the crown/hypocotyl within a $2 \mathrm{~cm}$ region. Both tissue $2 \mathrm{~cm}$ above the hypocotyl/crown and 2 $\mathrm{cm}$ below the hypocotyl/crown regions were free from infection. Only $2 \%$ of the infected seedlings showed distinct red necrosis at the crown region (Fig. 5a).

Seedlings with red necrosis at one side of the crown region had constricted cortical tissues and a large presence of EAM and infection hyphae, whereas tissue at the symptomless side of the sections was intact and free from EAM and hyphae. Vascular elements (xylem and phloem tissues) were also free from infection structures and EAM (Fig. 5b). Meanwhile, crown tissue of infected seedlings without necrosis contained infection hyphae in the epidermis and cortical tissues, with no infection occurring in the vascular elements and no EAM (Fig. 5c). The epidermis, cortex tissues and vascular elements of the epicotyl and radicle regions away from the infection zone (crown/hypocotyl) were not affected and had no EAM. No visible symptoms developed on the seedlings at 8 weeks after growth in potting mix in the glasshouse.

\section{Comparative establishment of seedlings from infected and heat-treated seeds}

Only 37 seedlings (30\%) developed from the 125 naturally infected seeds (cultivar BR1) in the glasshouse over 6 weeks. The average length of each seedling was approximately 10-12 $\mathrm{cm}$. Two of these seedlings showed distinct reddish necrosis at the crown region and $S$. tanaceti was recovered from both these seedlings. Stagonosporopsis tanaceti was also recovered from another eight seedlings that showed no necrotic symptoms at the crown region. The infection zone of $S$. tanaceti was confined to the crown/hypocotyl region (2-3 $\mathrm{cm}$ ), but both epicotyl and radicle regions were free from infection. The remainder of the 27 seedlings were free from $S$. tanaceti. All of the 104 viable seedlings (83\%) that developed from the 125 heat-treated seeds were symptomless and free from S. tanaceti. The other $17 \%$ of seeds failed to germinate. The average length of these seedlings was also 10-12 cm. 


\section{Discussion}

Pyrethrum seeds collected from naturally infected cultivars BR1 and RS5 showed no visible lesions, infection structures or physical deformities, thus making visual detection of infection in pyrethrum seed lots very difficult. The infection level was determined by culturing the seeds on WA followed by subculturing the mycelia onto V8 medium for 2 weeks to enable morphological identification of S. tanaceti (Pethybridge \& Wilson, 1998).

Histopathology revealed that $S$. tanaceti hyphae infected the seed coat but not the embryo. The outer layer was infected more than inner layer of the seed coat. All the embryos separated from infected seeds were free from infection and were able to develop into seedlings. The seed coat was thick $(80-105 \mu \mathrm{m})$ and multi-layered with a gap between the seed coat and the embryo that might act as a physical barrier to protect the embryo from infection. Pethybridge et al. (2005) reported that pyrethrum seeds were the primary means of transmission of $S$. tanaceti but the location of infection hyphae in the seed components was unknown. Lee et al. (1984) reported that Ascochyta cucumis (synonym: Didymella bryoniae) infected mostly the seed coat of pumpkin (Cucumis sativus) and rarely the embryo. Ascochyta fabae (synonym:D. fabae) only infected the seed coat but not the embryo of field bean (Vicia faba) (Hewett, 1973; Wallen \& Galway, 1977). In contrast, mycelia of A. rabiei infected both the seed coat and embryo of chickpea seeds (Cicer arietinum) (Nene, 1982).

The pyrethrum seed surface was not continuous, but rather had fissures or spaces and the pappus contained an empty space. Therefore, further studies need to be undertaken to determine if the fissures on the seed coat serve as an entry point for infection and whether the empty space around the pappus serves as the receptacle of air borne conidia for subsequent infection.

Infected seed coats enabled the hyphae to infect and colonize the parenchyma tissues of the developing embryos. Infected tissues were completely degraded and contained large amounts of extracellular anthocyanin like materials (EAM). Heavily infected embryos failed to germinate; however, the amount of infection hyphae needed to kill the embryo was not determined. Pre-emergence death of germinated embryos was probably dictated by the level of infection in the seed coat. Heavily infected seed coats enabled rapid infection and colonization of the developing embryo, resulting in pre-emergence death at 7 dai. Crown/hypocotyl tissues of seedlings that emerged from infected seed were infected and had 
a reddish necrotic lesion on tissue that was in contact with the seed coat. As the lesion extended towards the whole hypocotyl/crown region of the seedling, both the epidermis and cortical tissues became heavily infected and vascular elements accumulated deposits of EAM. The proportion of EAM was more in the heavily infected tissues than in less infected tissues. Similar large amounts of EAM were also observed previously in the S. tanaceti-infected mesophyll tissues of pyrethrum leaves at the advanced stage of infection (Bhuiyan et al., 2015). Saniewska \& Dyki (1997) reported that the red pigmentation on white petals of Hippeastrum was a result of infection by Stagonospora curtisii.

Embryos from infected seed that developed into seedlings most probably had low levels of infection, but precise estimation of the quantity of infection hyphae in these seedlings needs to be performed, for example, by using qPCR. Although, most of the infected seedlings $(\sim 80 \%)$ remained symptomless after 6 weeks growth in potting mix, infection hyphae were isolated from the crown/hypocotyl region of the infected seedlings. In these seedlings, although the epidermis and cortical tissues at the crown region were infected, the vascular tissues were completely uninfected. In this situation, the pathogen was either not able to cause severe necrosis or transitioned into a quiescent phase and coexisted with the developing seedling. Therefore, the three outcomes of host-pathogen interactions (preemergence death, post-emergence death and infected symptom/symptomless seedlings) were most probably determined by a combination of inoculum intensity in the infected seed coat and the favourable environmental conditions at the time of seed germination and seedling development. Similar outcomes were also reported in cucumber and pumpkin seed infected by A. bryoniae (Lee et al., 1984).

Knowledge of the location of infection hyphae in the seed and seedling will help in the development of effective control measures. Infected seedlings that remain symptomless and grow normally may be potential threats for the future development of ray blight epidemics once favourable conditions prevail. In 1999, the epidemic of ray blight disease of pyrethrum in Australia was assumed to be caused by seedborne infection (Pethybridge et al., 2011). Because hyphae of $S$. tanaceti remain only in the multi-layered thick walled seed coat, control methods such as fungicide seed treatments and thermal sterilization may be applied to the seed prior to planting to mitigate the risk of $S$. tanaceti infection in seedlings and, ultimately, prevent epidemics. Pethybridge et al. (2006) demonstrated that treatment of pyrethrum seeds with fludioxonil and thiabendazole/thiram significantly reduced the incidence of $S$. tanaceti and increased seed germination and survival. Incidence of $S$. tanaceti 
in seed can also be reduced significantly by applying fungicides in standing crops on a regular basis before harvest (Pethybridge et al., 2005). Nevertheless, circumstantial evidence has shown that ray blight infection still occurs in crops established from treated seeds. Thermotherapies using hot water, hot air, solar heat, aerated steam and radiation have been suggested as treatments for pyrethrum seeds to eliminate fungal seedborne pathogens (Pethybridge et al., 2006); however, the efficacy of these treatments to control seed infection by $S$. tanaceti has yet to be reported. Thermal treatment could be used prior to an application of seed-treating fungicides to control $S$. tanaceti if the intensity and duration of temperature are optimized to prevent harm of the viability and vigour of the pyrethrum seed. According to Schmitt et al. (2009), a combination of hot water, aerated steam, electron treatment and thyme oil (0.1\%) was shown to reduce seedborne levels of Phoma or Septoria spp. on carrot, cabbage or lamb's lettuce seeds without affecting seed germination.

This study has identified the process of $S$. tanaceti infection and colonization in pyrethrum seed and seedlings. Improved understanding of this process will assist in the development of seed treatments to reduce the incidence of $S$. tanaceti in seed lots and reduce the transmission of the pathogen in growing crops in the field. According to Pethybridge et al. (2006) an incidence of $S$. tanaceti above $28 \%$ in a commercial seed lot is of great concern for epidemic development of the pathogen in future crops. The development of a qPCR technique to quantify the infection hyphae could be adopted to screen pyrethrum seed lots before planting.

\section{Acknowledgements}

This project was supported by Botanical Resources Australia (BRA)-Agricultural Services Pty. Ltd.

\section{References}

Bhuiyan MAHB, Groom T, Nicolas ME, Taylor PWJ, 2015. Histopathology of S. tanaceti infection in pyrethrum leaf lamina. Australasian Plant Pathology 44, 629-36.

van den Bosch F, Fraaije BA, van den Berg F, Shaw MW, 2010. Evolutionary bi-stability in 
pathogen transmission mode. Proceedings of the Royal Society B: Biological Sciences 277, 1735-42.

Hay FS, Gent DH, Pilkington SJ, Pearce TL, Scott JB, Pethybridge SJ, 2015. Changes in distribution and frequency of fungi associated with a foliar disease complex of pyrethrum in Australia. Plant Disease 99, 1227-35.

Hewett PD, 1973. The field behaviour of seed-borne Ascochyta fabae and disease control in field beans. Annals of Applied Biology 74, 287-95.

Hitmi A, Coudret A, Barthomeuf C, 2000. The production of pyrethrins by plant cell and tissue cultures of Chrysanthemum cinerariaefolium and Tagetes species. Critical Reviews in Biochemistry and Molecular Biology 35, 317-37.

Johansen DA, 1940. Plant Microtechnique. New York NY, USA: McGraw-Hill.

Lee DH, Mathur SB, Neergaard P, 1984. Detection and location of seed-borne inoculum of Didymella bryoniae and its transmission in seedlings of cucumber and pumpkin. Journal of Phytopathology 109, 301-8.

MacCoy RE, 1973. Ballistics of Mycosphaerella ligulicola ascospores discharge. Phytopathology 63, 793-4.

Nene YL, 1982. A review of ascochyta blight of chickpea. Tropical Pest Management 28, $61-70$.

Oliver E, Thrall P, Burdon JJ, Ash JE, 2001. Vertical disease transmission in the CakileAlternaria host-pathogen interaction. Australian Journal of Botany 49, 561.

Pethybridge SJ, Wilson CR, 1998. Confirmation of ray blight disease of pyrethrum in Australia. Australasian Plant Pathology 27, 45-8.

Pethybridge SJ, Hay F, Groom T, 2003. Seasonal fluctuations in fungi associated with pyrethrum foliage in Tasmania. Australasian Plant Pathology 32, 223-30.

Pethybridge SJ, Hay FS, Wilson CR, Groom T, 2005. Development of a fungicide-based management strategy for foliar disease caused by Phoma ligulicola in Tasmanian pyrethrum fields. Plant Disease 89, 1114-20. 
Pethybridge SJ, Hay F, Jones S, Wilson C, Groom T, 2006. Seedborne infection of pyrethrum by Phoma ligulicola. Plant Disease 90, 891-7.

Pethybridge SJ, Esker P, Dixon P et al., 2007. Quantifying loss caused by ray blight disease in Tasmanian pyrethrum fields. Plant Disease 91, 1116-21.

Pethybridge SJ, Hay FS, Esker PD et al., 2008. Diseases of pyrethrum in Tasmania: challenges and prospects for management. Plant Disease 92, 1260-72.

Pethybridge SJ, Gent DH, Hay FS, 2011. Epidemics of ray blight on pyrethrum are linked to seed contamination and overwintering inoculum of Phoma ligulicola var. inoxydabilis. Phytopathology 101, 1112-21.

Saniewska A, Dyki B, 1997. Induction of red pigment in white petals of Hippeastrum $\times$ Hybr. Hort. during infection by Phoma narcissi (Aderh.) Boerema, De Gruyter et Noordel., comb. nov. and by mechanical injuries. Acta Agrobotanica 50, 41-8.

Schmitt A, Koch E, Stephan D et al., 2009. Evaluation of non-chemical seed treatment methods for the control of Phoma valerianellae on lamb's lettuce seeds. Journal of Plant Diseases and Protection 116, 200-7.

Vaghefi N, Pethybridge S, Ford R, Nicolas M, Crous P, Taylor P, 2012. Stagonosporopsis spp. associated with ray blight disease of Asteraceae. Australasian Plant Pathology 41, 675-86.

Vaghefi N, Ades PK, Hay FS, Pethybridge SJ, Ford R, Taylor PWJ, 2015a. Identification of the MAT1 locus in Stagonosporopsis tanaceti, and exploring its potential for sexual reproduction in Australian pyrethrum fields. Fungal Biology 119, 408-19.

Vaghefi N, Hay F, Ades P, Pethybridge S, Ford R, Taylor PWJ, 2015b. Rapid changes in the genetic composition of Stagonosporopsis tanaceti population in Australian pyrethrum fields. Phytopathology 105, 358-69.

Wallen V, Galway D, 1977. Studies on the biology and control of Ascochyta fabae on faba bean. Canadian Plant Disease Survey 57, 31-5.

Zito SW, Zieg RG, Staba EJ, 1983. Distribution of pyrethrins in oil glands and leaf tissue of Chrysanthemum cinerariaefolium. Planta Medica 47, 205-7. 


\section{Figure legends}

Figure 1 (a) A mature pyrethrum seed (cultivar BR1/RS5) showing distinct ribs/ridges (r) and a pappus (p). (b) An empty space (es) around the pappus (p). (c) Dissected pyrethrum seed (cultivar BR1/RS5) showing outer layer (ol) and inner layer (il) of seed coat and an embryo (emb). (d) Longitudinal section of pyrethrum seed (cultivar BR1/RS5) consisting of seed coat covered with a waxy cuticle (cu) layer; seed coat composed of outer layer (ol) (multicelled thick sclerenchyma layer) followed by first inner layer (il) (single cell-thick sclerenchyma layer), second inner layer (single cell-thick parenchyma layer) and an embryo (emb) which consisted of multicelled thick parenchyma layers positioned apart from the seed coat, leaving a gap between the seed coat and the embryo. (e) Longitudinal section of outer layer (ol), showing some fissures/spaces (black arrowhead). (f) Longitudinal section of seed (cultivar BR1/RS5) infected with Stagonosporopsis tanaceti, showing infection hyphae (black arrowhead) inside the outer layer (ol) of the seed coat. Scale bars in a, b \& c $=250$ $\mu \mathrm{m} ; \mathrm{d}, \mathrm{e} \& \mathrm{f}=10 \mu \mathrm{m}$.

Figure 2 Pyrethrum seedlings infected with Stagonosporopsis tanaceti. (a) Small necrotic lesion (white arrowhead) at the hypocotyl/crown region of the cotyledon that emerged from the infected seed coat (cultivar BR1) at 3 days after incubation (dai). (b) Extended red necrotic lesion (white arrowhead) observed at the crown region of infected seedling at 7 dai.

Figure 3 Infection of pyrethrum seeds (cultivar BR1) by Stagonosporopsis tanaceti. (a) Hypha (black arrow) observed in the fissures of the outer layer (ol) of the seed coat in longitudinal section (LS). (b) Intra- (black arrow) and intercellular (white arrow) hyphae in sclerenchyma cells in a transverse section of the outer layer (ol) of the seed coat. (c) Infection hypha (insert, black arrowhead) observed in between the outer layer (ol) and inner layers (il) of the seed coat, in LS. (d) Hyphae (black arrow) from the seed coat (sc) infecting the embryo (emb) at 5 days after incubation (dai) without changing the tissue composition of the embryo; observed in LS. (e) Longitudinal section of infection hyphae (black arrow) colonizing around the outer surface of the the embryo (emb) at 6 dai; infected tissues are light yellowish brown. (f) Longitudinal section of infection at 7 dai; epidermal tissues of the embryo (emb) have disintegrated and become necrotic (yellow) due to the presence of infection hyphae (black arrowhead); red extracellular anthocyanin-like material (white arrowhead) can be seen on the edge of the infected embryo. Scale bars $=10 \mu \mathrm{m}$. 
Figure 4 (a) Complete digestion of embryonic (emb) cells of pyrethrum seeds (cultivar BR1), infected with Stagonosporopsis tanaceti, that failed to germinate (pre-emergence death) at 7 days after incubation (dai). Cells are replaced by extracellular anthocyanin-like material (EAM) (white arrowhead) and infection hyphae (black arrowhead); viewed in longitudinal section. (b) Death of infected seedling at 10-14 dai, showing three growing regions (radicle, crown/hypocotyl and epicotyl), with deep red necrosis in the entire radicle and crown region. (c) Transverse section of an infected cotyledon at the crown region, showing that cortical tissues contain red EAM; most of the epidermal (epi) and cortical tissues are degraded; xylem (x) vessels and phloem (ph) tissues contain EAM (white arrowhead) except for few of the central xylem ( $\mathrm{x}$ ) vessels. (d) Longitudinal section of an infected cotyledon showing that the xylem (x) vessels are free from infection hyphae and EAM but the phloem (ph) tissues are replaced by EAM. (e) Longitudinal section of an infected seedling also showing cortical (cort) tissues replaced by hyphae (black arrowhead) and EAM (white arrowhead); most of the cells are lysed and cell contents digested. Scale bars in a, c, d \& e $=10 \mu \mathrm{m} ; \mathrm{b}=250 \mu \mathrm{m}$.

Figure 5 (a) Pyrethrum seedling (cultivar BR1) infected by Stagonosporopsis tanaceti but with no symptoms, showing three distinct growing regions (epicotyl/shoot, crown/hypocotyl and radicle), 6 weeks after germination. (b) Transverse section at the crown/hypocotyl region of an infected seedling with red lesion, showing red EAM (black arrowhead) and infection hyphae (white arrowhead) in cortical (cort) tissues from the constricted side of the section; the vascular elements such as phloem (ph) tissues and xylem (x) vessels are organized, wellstructured and free from hyphae and extracellular anthocyanin-like material (EAM); the symptomless side of the tissue is free from EAM and hyphae. (c) Transverse section at the crown/hypocotyl region of an infected seedling without red lesions at the crown/hypocotyl region. Although infection hyphae (black arrowhead) are present, red EAM is absent in the cortical tissues and xylem (x) vessels are free from infection hyphae and EAM. Scale bars in $\mathrm{a}=1 \mathrm{~cm} ; \mathrm{b} \& \mathrm{c}=10 \mu \mathrm{m}$.

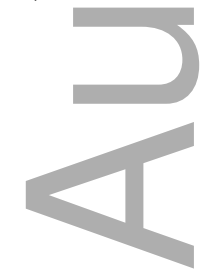


Table 1 Classification of seed development based on occurrence of infection at 14 days after incubation on water agar

Mean of occurrence

\begin{tabular}{ll} 
Classification & $(\%)^{\mathrm{a}}$ \\
\hline Seeds resulting in healthy seedlings & $44.7 \mathrm{a}$ \\
Non-viable seeds failed to germinate (noninfected) & $21.3 \mathrm{~b}$ \\
Seeds resulting in pre-emergence death by Stagonosporopsis & $19.3 \mathrm{~b}$ \\
tanaceti & $9.0 \mathrm{c}$ \\
Seeds resulting in infected seedlings by S. tanaceti & $3.7 \mathrm{~d}$ \\
Seeds resulting in post-emergence death by S. tanaceti & $2.0 \mathrm{~d}$ \\
Seeds resulting in germination failure caused by fungi other than S. \\
tanaceti
\end{tabular}

${ }^{a}$ Mean of occurrence in 15 seeds per plate with 20 replications. Values within the same column followed by the same letter are not significantly different at $\mathrm{P}>0.05$ according to Tukey's honestly significant difference mean separation test. 


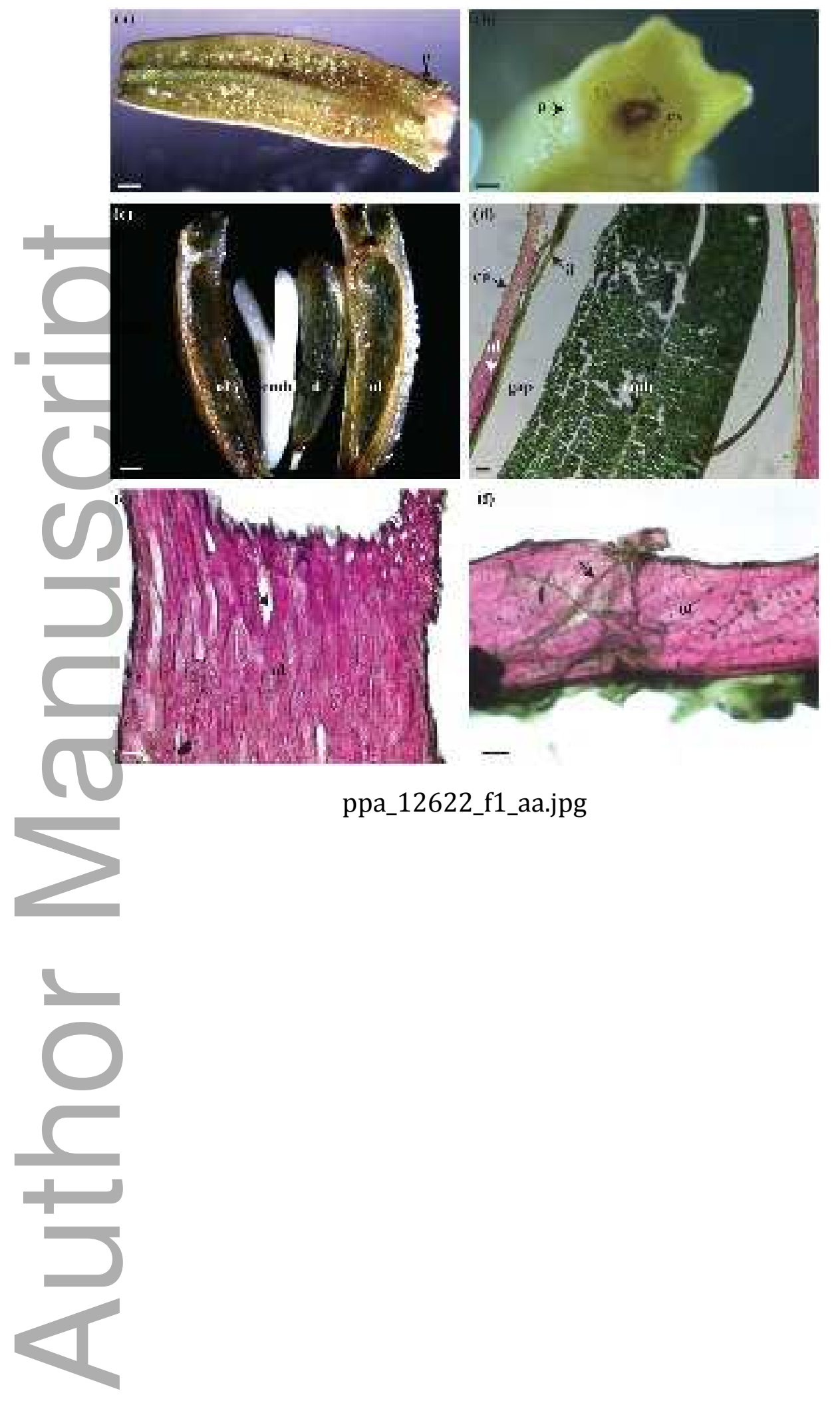

This article is protected by copyright. All rights reserved 


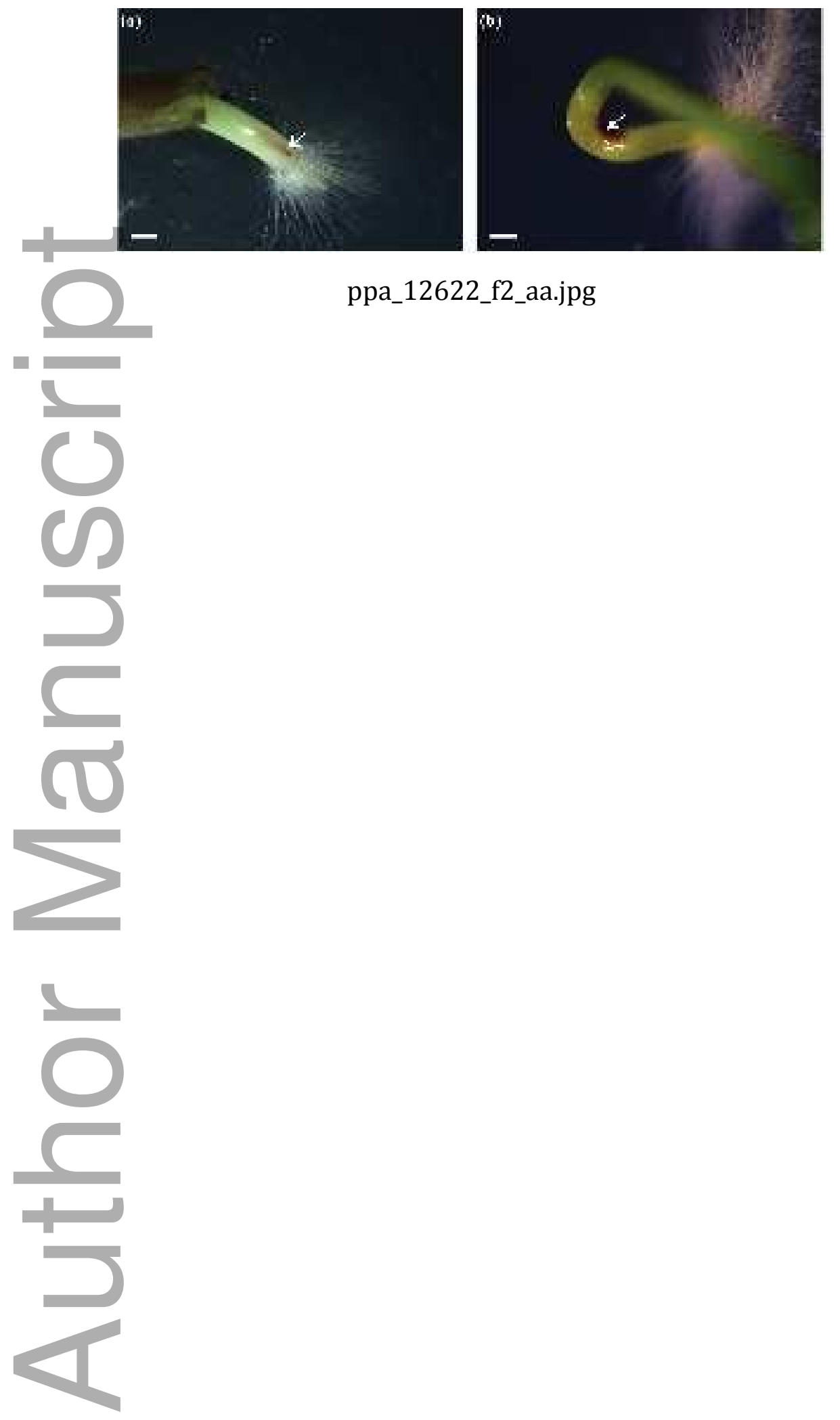

This article is protected by copyright. All rights reserved 

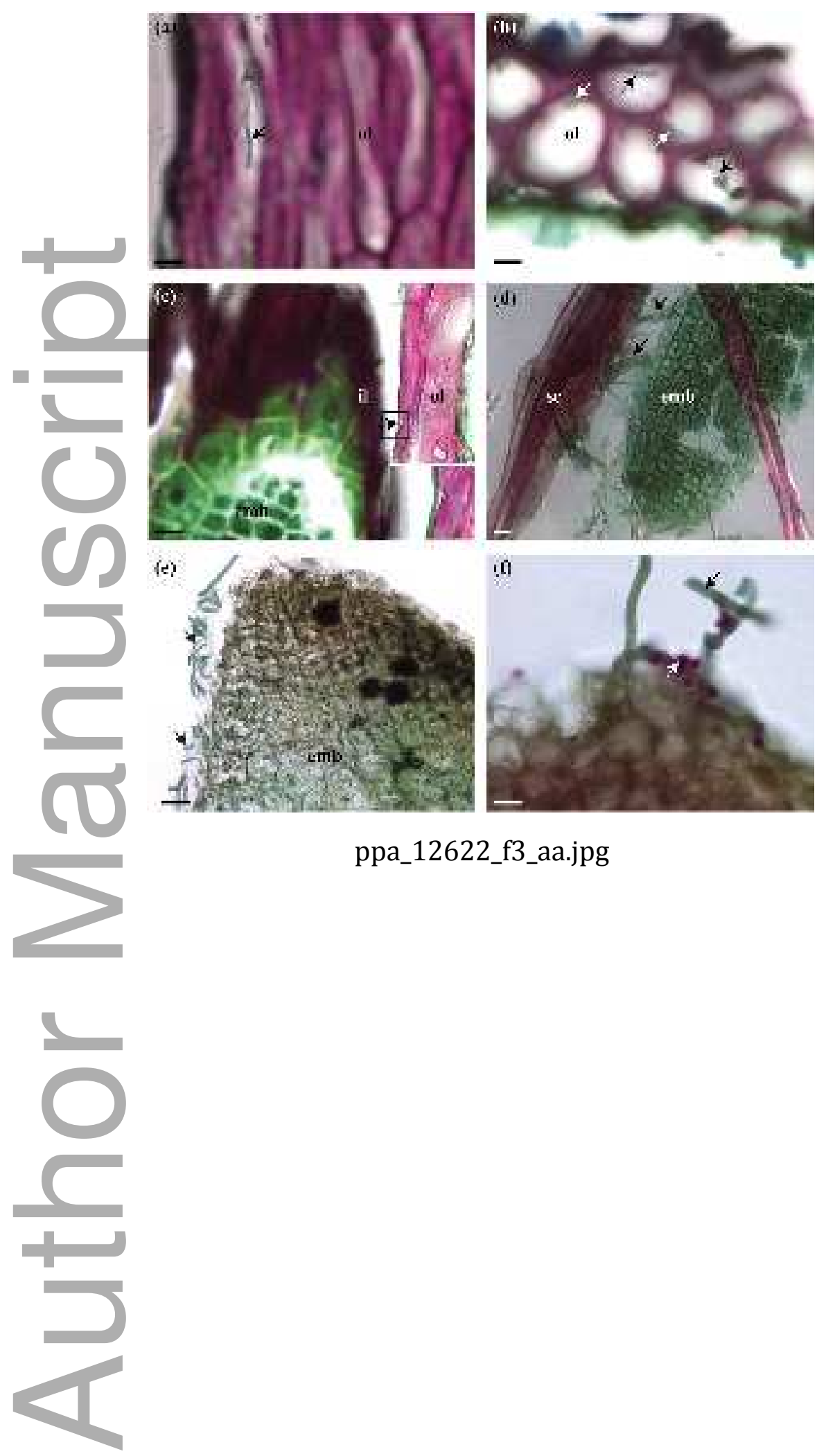

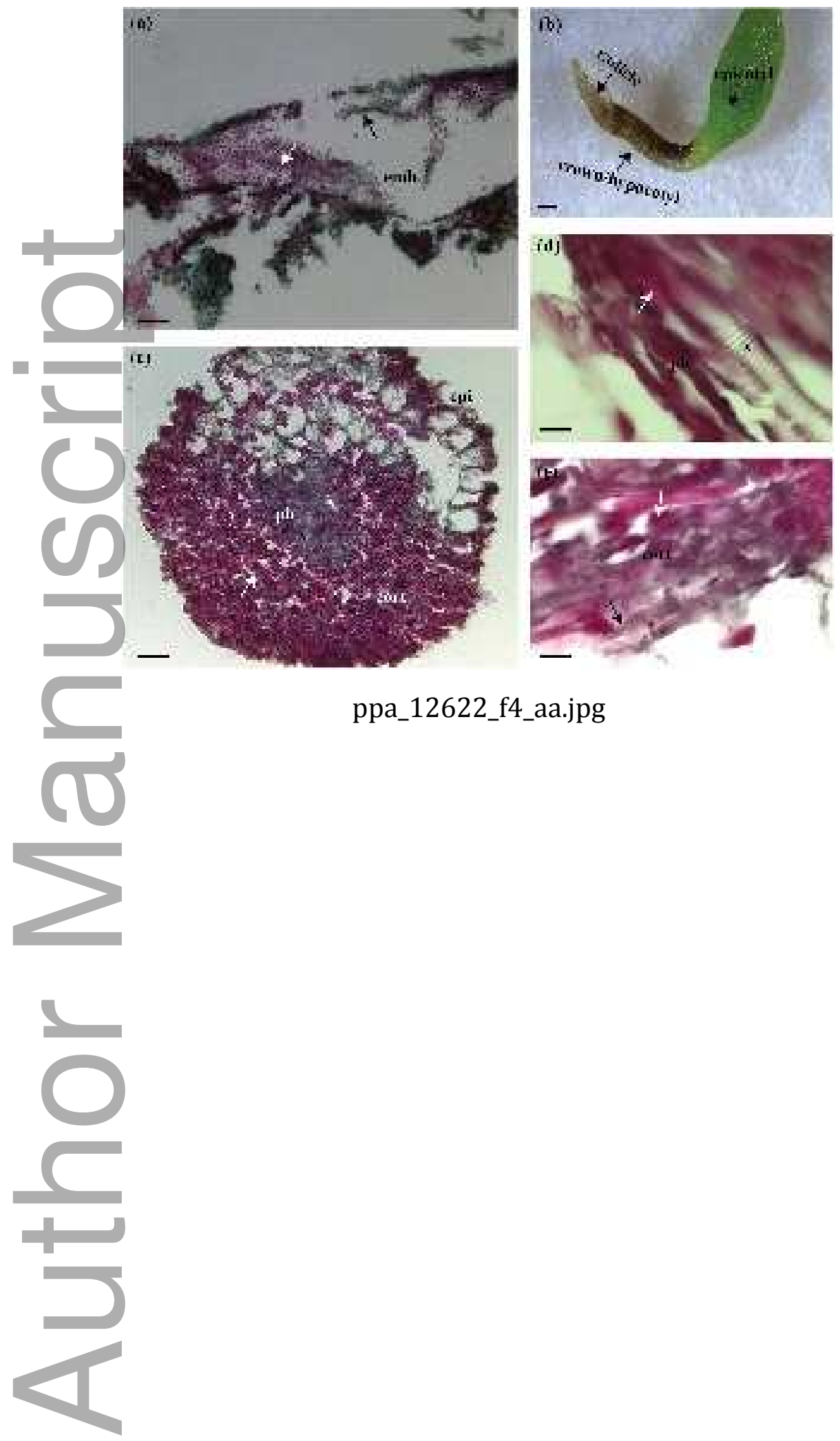

This article is protected by copyright. All rights reserved 

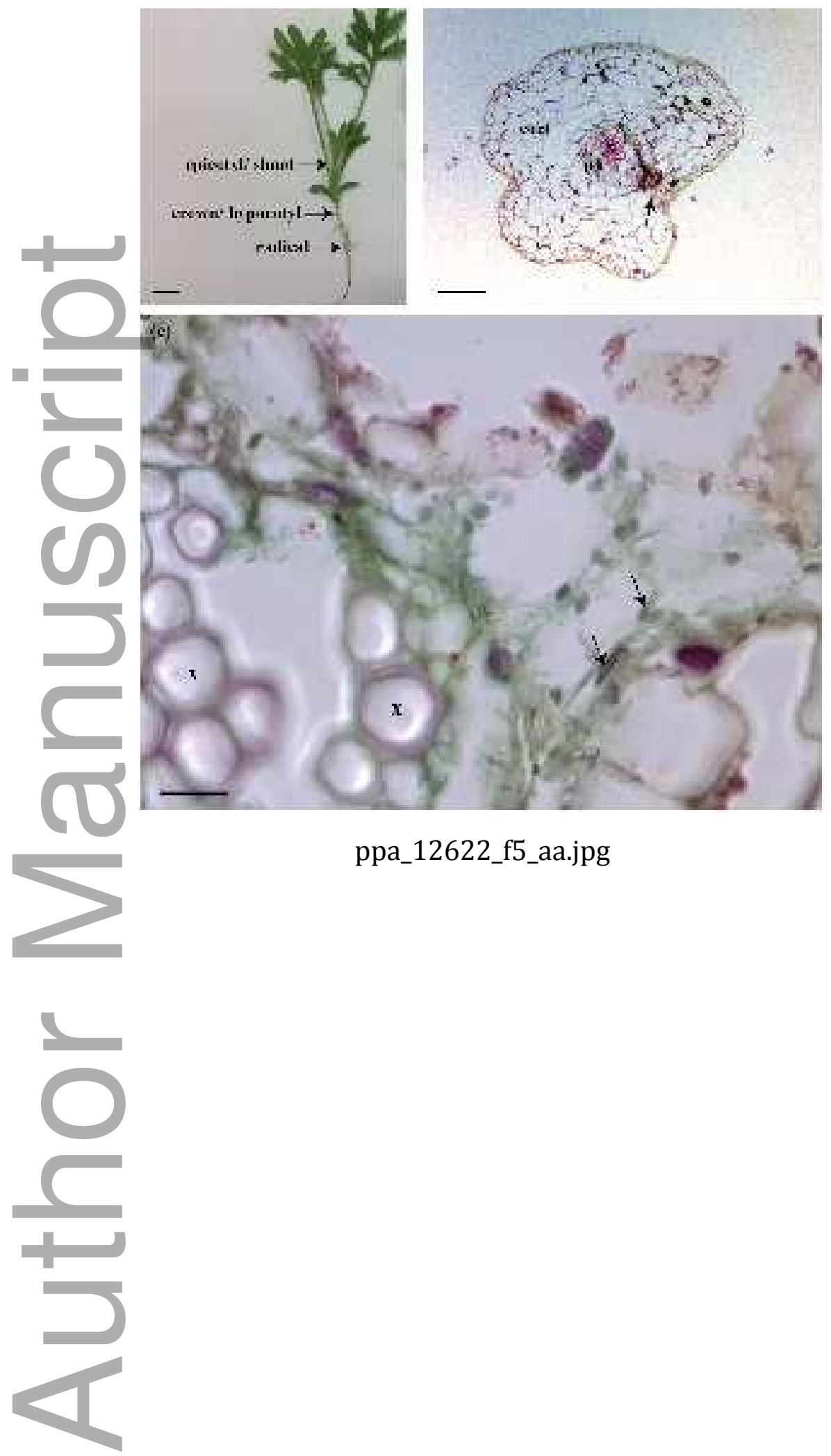


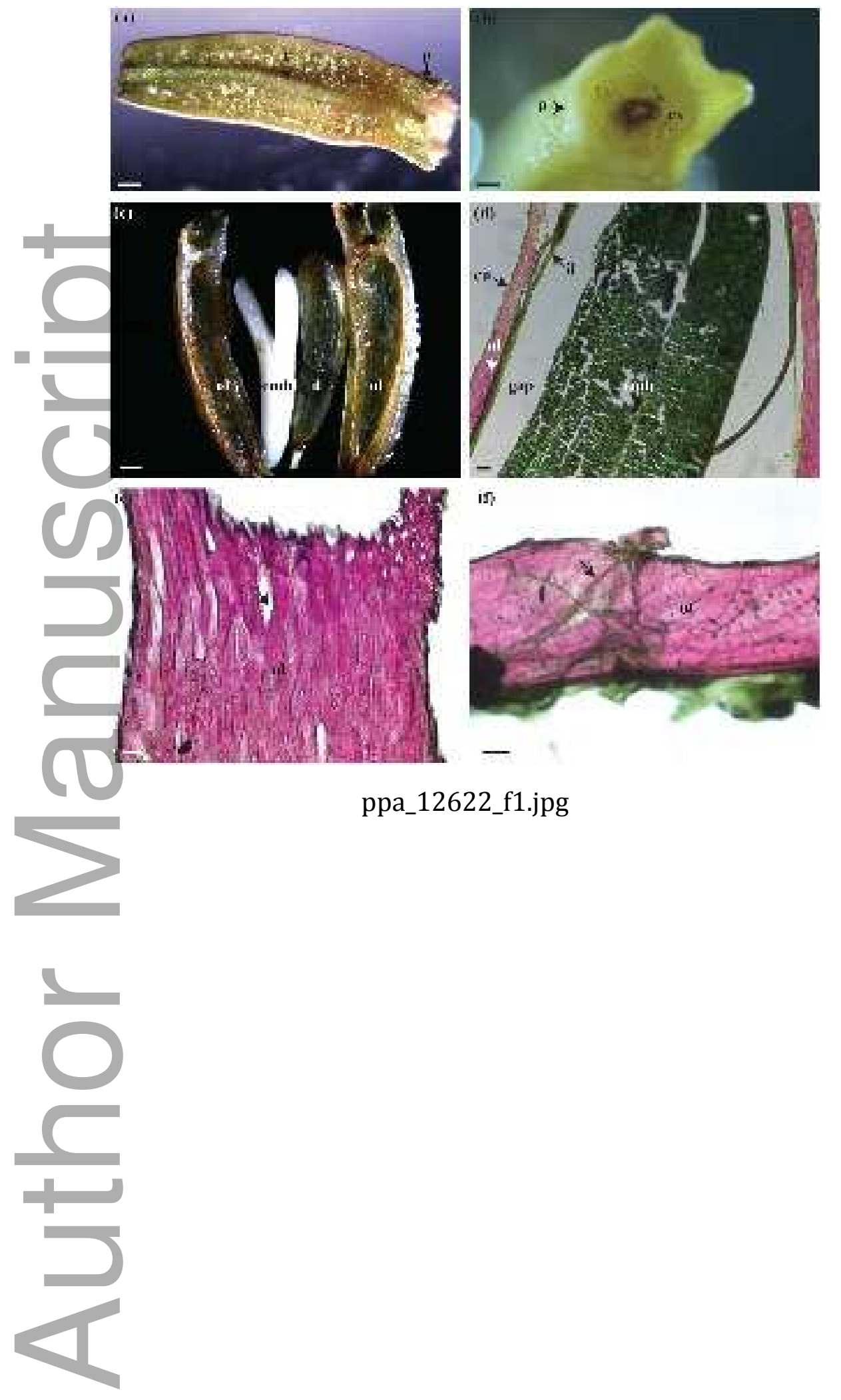

This article is protected by copyright. All rights reserved 


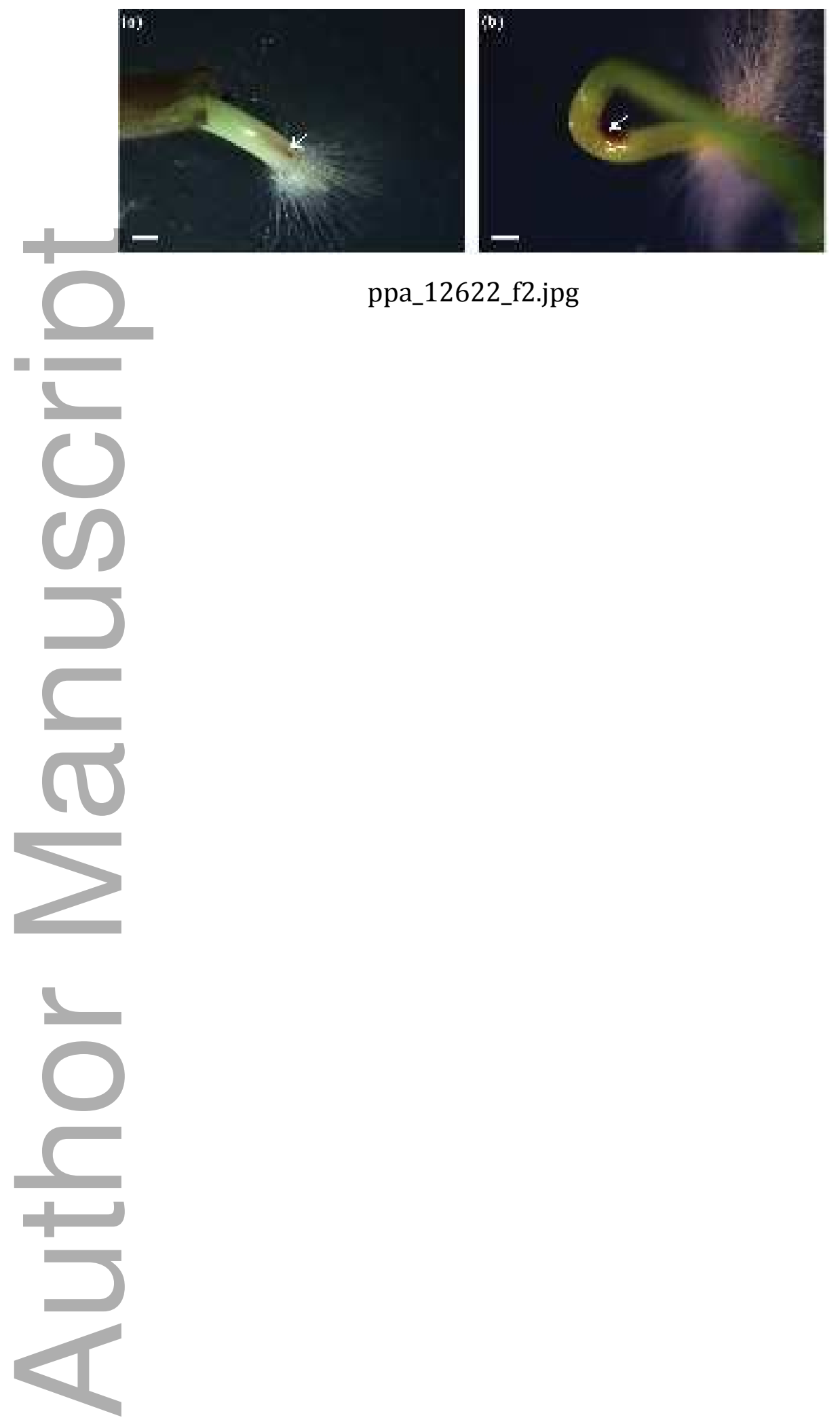

This article is protected by copyright. All rights reserved 

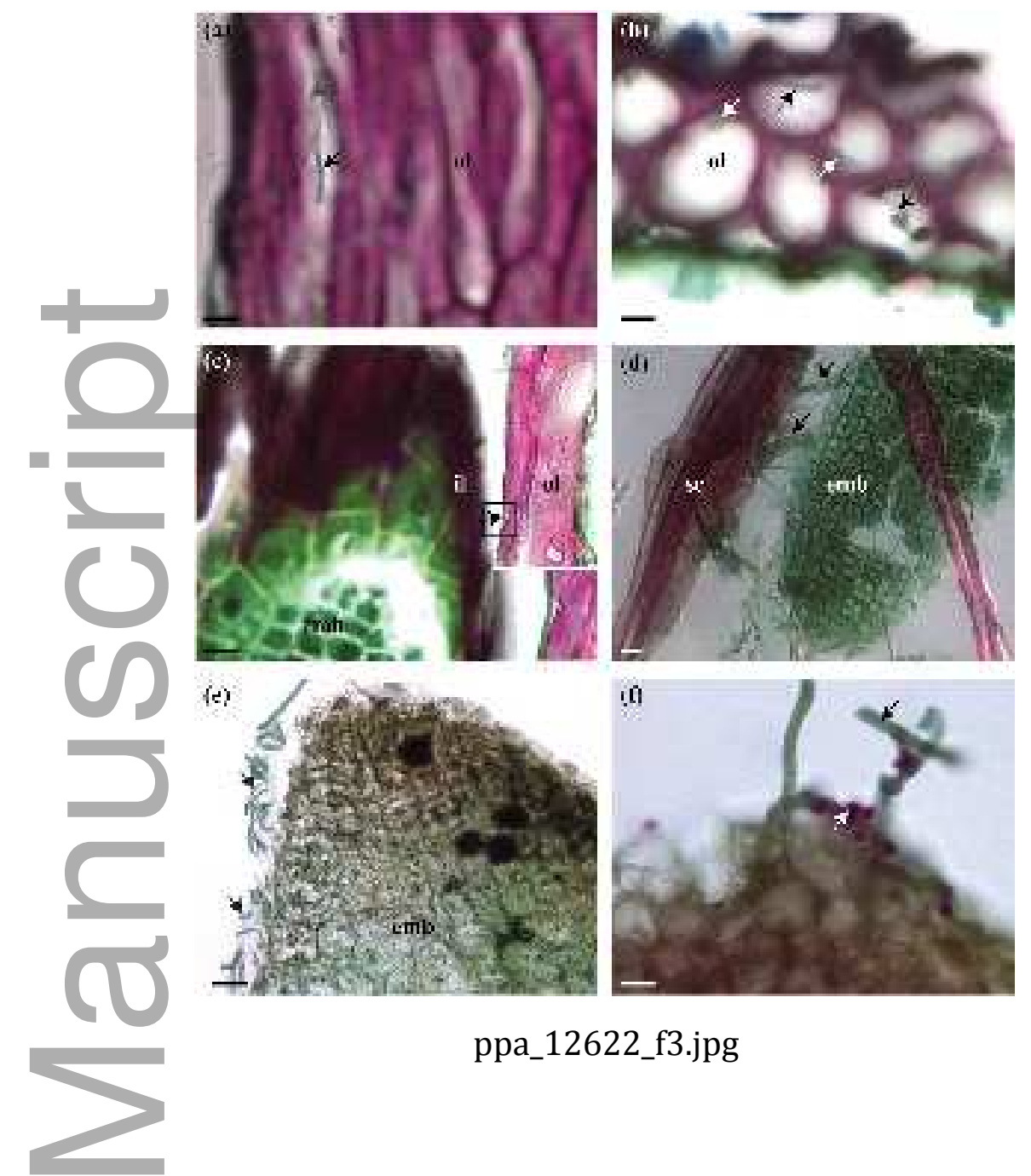

ppa_12622_f3.jpg

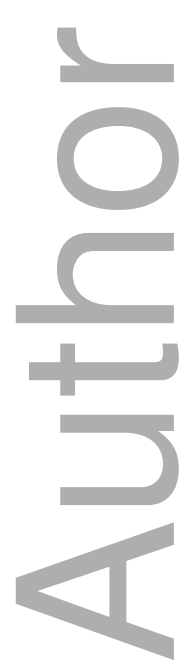



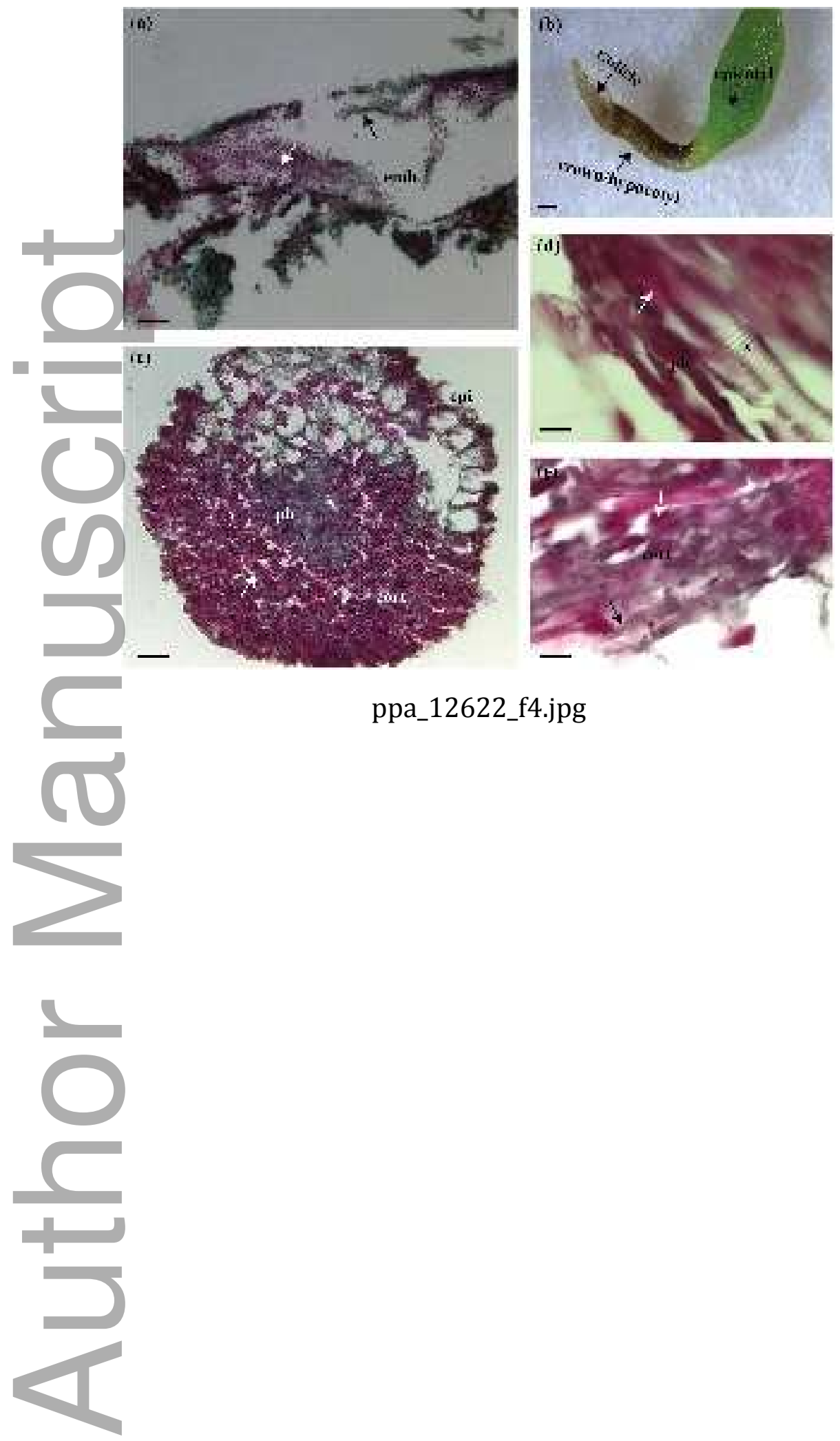

This article is protected by copyright. All rights reserved 

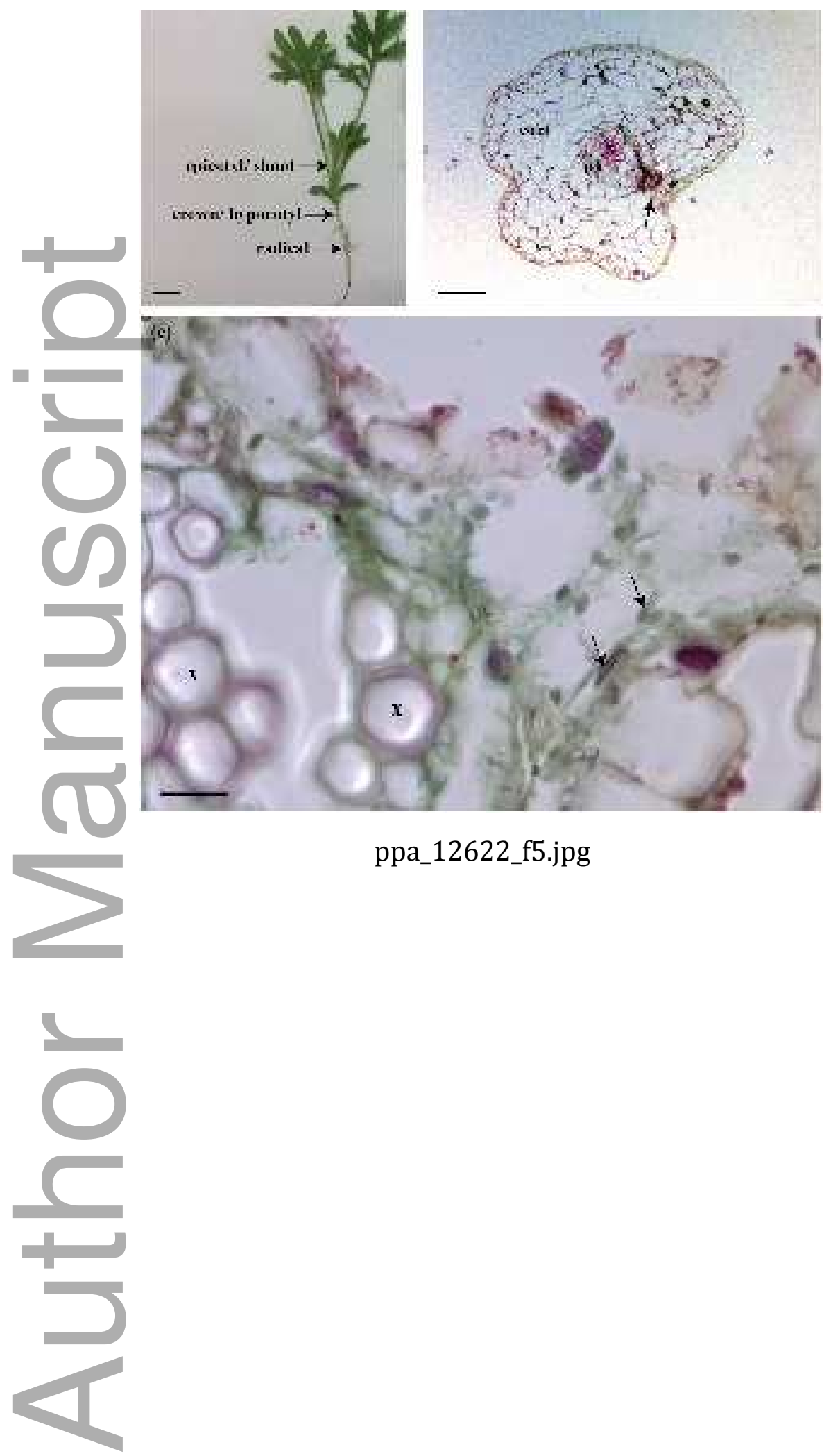


\section{University Library}

\section{- M M N E R VA A gateway to Melbourne's research publications}

Minerva Access is the Institutional Repository of The University of Melbourne

Author/s:

Bhuiyan, MAHB;Groom, T;Nicolas, ME;Taylor, PWJ

Title:

Infection process of Stagonosporopsis tanaceti in pyrethrum seed and seedlings

Date:

2017-06-01

Citation:

Bhuiyan, M. A. H. B., Groom, T., Nicolas, M. E. \& Taylor, P. W. J. (2017). Infection process of Stagonosporopsis tanaceti in pyrethrum seed and seedlings. PLANT PATHOLOGY, 66 (5), pp.743-751. https://doi.org/10.1111/ppa.12622.

Persistent Link:

http://hdl.handle.net/11343/291856 